\title{
New records of scuttle flies (Diptera: Phoridae) from caves in the Bakony Mountains, Hungary
}

\author{
R. Henry L. DisNeY*, Csaba KuTASI** Lajos Tamás KATONA** and Sándor TóTH**** \\ *Department of Zoology, University of Cambridge, Cambridge CB23EJ, England; e-mail: rhld2@hermes.cam.ac.uk \\ **Bakony Museum of the Hungarian Natural History Museum, ZIRC, Hungary; \\ e-mails: kutasi@index.hu, finci99@freemail.hu \\ ***H-8420 ZIRC, Széchenyi u. 2, Hungary; e-mail:flycatcher@vnet.mu
}

\begin{abstract}
Eleven species of Phoridae were obtained during the survey of invertebrates fauna of four caves in the Bakony Mountains of Hungary. Four species are new records for Hungary: Borophaga bennetti Disney, 2010, Megaselia tenebricola Schmitz, 1934, Megaselia vernalis (Wood, 1909) and Triphleba flexipalpis Schmitz, 1927.
\end{abstract}

Key words: Diptera, Phoridae, caves, Bakony Mountains, Hungary, new records

\section{INTRODUCTION}

The biospeleological researches on the Hungarian caves have a great tradition (Horusitzky \& Siegmeth 1914). Unfortunately in recent decades only few investigations have been carried out.

All caves in Hungary have been protected since 1961. Most of the caves are in the Bükk and Bakony mountain ranges. The Bakony Mountains are the most complex geological region in Hungary. The mountains are composed of numerous karst-, and non-karstic (sedimentary and volcanic) caves. As a consequence, the caves are very diverse (Eszterhás \& Szentes 2013).

In 2009 the staff of the Natural History Museum of Bakony Mountains and the local caver clubs started to discover the cave fauna of the Bakony Mts Some of these caves, were never zoologically studied before.

One of the previously investigated caves is the Lóczy Cave, where 50 years ago Imre Loksa collected 21 species of arthropods (Oniscoidea, Diplopoda, Diplura, Collembola, Pseudoscorpionidea, Araneae), using pitfall traps (Loksa 1960).

About 30 years ago, István Eszterhas collected invertebrates from Kapolcsi Pokol Hole. He has published data on 20 arthropods (Collembola, Isopoda, Diplopoda, Araneae, Lepidoptera, Diptera). Among Diptera, he found the individuals of the three genera belonged to the family Phoridae (Phora sp., Megaselia sp., Conicera sp.) (Eszterhás 1986). These individuals were identified to genera level only. Unfortunately, the collected material has been lost.

\section{PLACE AND METHODS OF THE STUDY}

Between 2009 and 2012 invertebrates were collected in one small basalt cave and three limestone caves in the Bakony Mountains (Fig. 1). The three studied caves are under the management of the Balaton-felvidéki National Park, they are partly open to the public.

The Csodabogyós Cave is situated at Balatonederics, in the Keszthely Mts. which is part of the Bakony Mts. The cave formed in the Late Triassic period in Ederics Limestone formation. It is a $5200 \mathrm{~m}$ long and 121 deep multi level system of fissures cave. The cave chambers are notable for various dripstone formations, therefore it has been strictly protected since 1992 (Kárpát 2003, Anonymus 2012). 
The Lóczy Cave is near Balatonfüred. It was discovered in 1882 . The $154 \mathrm{~m}$ long and $15 \mathrm{~m}$ deep cave was formed by upwelling thermal water in Füred Limstone in the Late Triassic period, and it has been highly protected too since 1982 (Hazslinszky 2003, Anonymus 2012).

The Takó Cave is near Eplény. It is a $60 \mathrm{~m}$ long limestone cave (Anonymus 2012).

The Kapolcsi Pokol Hole is a $56 \mathrm{~m}$ long tectonic basalt cave. The thick basalt blocks in this cave dam the seeping water, which emerges as a spring. This spring feeds a small lake. The size of the lake varied, because after the water reaches a certain level a siphon system drains it. The lake appears mainly in the spring, after thawing (Eszterhás \& Szentes 2010).

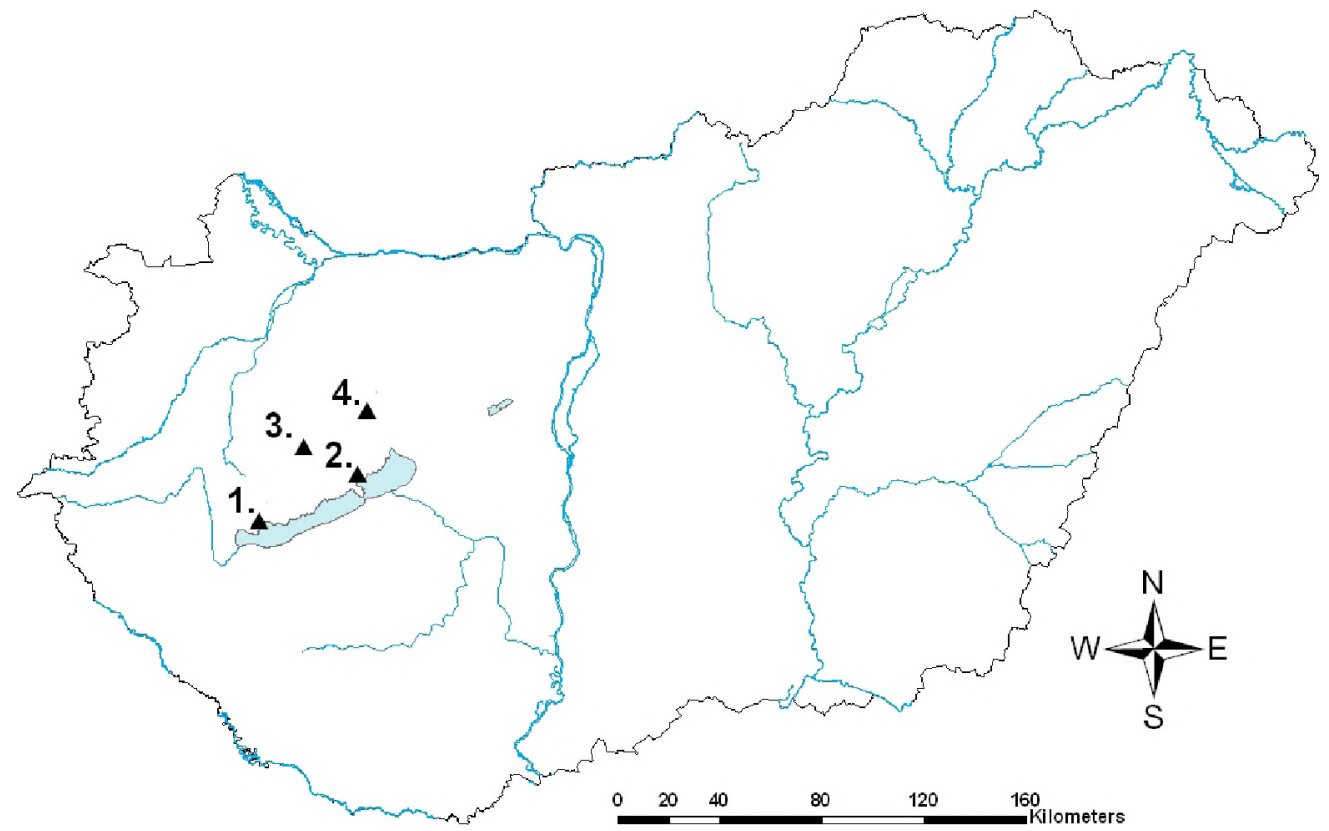

Fig. 1. Location of the studied caves in Hungary: 1 - Csodabogyós cave, Balatonederics (B-C), 2 - Lóczy cave, Balatonfüred (B-L), 3 - Pokol cave, Kapolcs (K-P), 4 - Takó cave, Veszprém (V-T).

The invertebrates were collected during a few visits in each cave between March 2009 and December 2012, using $250 \mathrm{~cm}^{3}$ volume pitfall traps, filled with ethylene glycol. Twelve traps in each cave were arranged from the entrance of the cave till the last viable parts. Stinking cheese was used as bait material. The arthropod material has been separated into orders. All specimens were preserved in $70 \%$ ethanol.

The material of Phoridae was identified by RHL Disney. The specimens from the samples were mounted on slides in Berlese Fluid (Disney 2001) and examined under a compound microscope, and deposited in the University of Cambridge Museum of Zoology.

The codes for the labels for the samples (coordinates and altitude) from the four caves are as follows:

B-C = Balatonederics: Csodabogyós-barlang limestone cave: $46^{\circ} 47.822^{\prime}$ N, $17^{\circ} 21.873$ ' E, 396 m a.s.1.

$\mathrm{B}-\mathrm{L}=$ Balatonfüred: Lóczy-barlang limestone cave: $46^{\circ} 58.140^{\prime} \mathrm{N}, 17^{\circ} 52.409^{\prime} \mathrm{E}, 248 \mathrm{~m}$ a. s. 1 .

K-P = Kapolcs: Pokol Hole (“Hell Cave") basalt cave: $46^{\circ} 56.823^{\prime}$ N, $17^{\circ} 35.302^{\prime}$ E, $272 \mathrm{~m}$ a.s.l.

$\mathrm{V}-\mathrm{T}=$ Veszprém: Takó-barlang limestone cave: $47^{\circ} 11.702^{\prime} \mathrm{N}, 17^{\circ} 54.974^{\prime} \mathrm{E}, 354 \mathrm{~m}$ a.s.1. 


\section{RESULTS}

The scuttle flies found in the four caves belonged to eleven species. Of the 461 specimens collected $172(37.3 \%)$ were males and $289(62.7 \%)$ were females.

\section{Borophaga bennetti Disney, 2010}

Material: K-P, 28 Mar-5 Jul 2012, 1 male, 1 female; K-P, 7 Jul-13 Nov 2012, 11 males, 4 females.

Remarks: This is a new record for Hungary, but it was only recently distinguished from two similar species (Disney 2010). It was previously only known from the British Isles.

\section{Diplonevra florescens (Turton, 1801) \\ (Bibio florea Fabricius, 1794)}

Material: B-C, 5 Jun-19 Oct 2010, 3 females.

Remarks: The larvae feed on invertebrate and vertebrate carrion, including occasionally on human corpses (Disney 2006), but females visit carrion not only to oviposit but also to obtain a protein rich meal when their eggs are still immature (Disney 1994).

\section{Megaselia breviterga (Lundbeck, 1920)}

Material: K-P, 7 Jul-13 Nov 2012, 1 female.

Remarks: The identification of this species has been recently clarified with the recognition that specimens reported from caves in the Nearctic Region belong to a sibling species (Disney 2012c). Females have been reported on dead mice, but less than a quarter were gravid (Disney 2012b, 2013).

\section{Megaselia pleuralis (Wood, 1909)}

Material: K-P, 7 Jul-13 Nov 2012, 1 female.

Remarks: The recognition of the females of this species has been recently clarified (Disney 2012a). It has been reared from pigeon dung and other decaying materials (Disney 1994).

\section{Megaselia posticata (Strobl, 1898)}

Material: K-P, 28 Mar-5 Jul 2012, 1 male 2 females; K-P, 7 Jul-13 Nov 2012, 2 male, 1 female.

\section{Megaselia rufipes (Meigen, 1804)}

Material: V-T, 12 May 2009-30 Jan 2010, 1 female; B-C, 5 Jun-19 Oct 2010, 7 females; K-P, 28 Mar-5 Jul 2012, 1 female; K-P, 7 Jul-13 Nov 2012, 2 males.

Remarks: The larvae feed on a wide range of decaying organic materials, including vertebrate carrion and hence their occurrence in forensic cases (Disney 1994). Adults are common in caves in Europe, for example in Belgium (Leruth 1936, 1939), Germany (Weber 1989, Prescher \& Zaeniker 2005), Spain (Disney 2009), and the Balkan Peninsula (Langourov 2002); and also in Afghanistan (Lindberg 1961, 1962).

\section{Megaselia tenebricola Schmitz, 1934}

Material: K-P, 28 Mar-5 Jul 2012, 1 male.

Remarks: This appears to be new record for Hungary. The species is common in caves elsewhere in Europe (e.g. Langourov 2002, Pérez Fernández 2007, Disney 2009). 


\section{Megaselia vernalis (Wood, 1909)}

Material: K-P, 28 Mar-5 Jul 2012, 1 male.

Remarks: This appears to be a new record for Hungary. It has been reported from caves in Germany (Prescher \& Zaenker 2005) and Spain (Pérez Fernández 2006).

\section{Triphleba antricola (Schmitz, 1918)}

Material: V-T, 12 May 2009-30 Jan 2010, 6 males, 10 females; V-T, 5 Dec 2009-30 Jan 2010, 5 males, 6 females; B-C, 17 Dec 2009-27 Feb 2010, 23 males, 29 females; B-C, 17 Dec 2009-27 Feb 2010, 78 males, 110 females; B-C, 5 Jun-19 Oct 2010, 3 males, 14 females; B-C, 27 Feb-5 Jun 2010, 6 males, 8 females; B-C, 27 Feb-5 Jun 2010, 9 males, 5 females; B-C, 5 Jun-19 Oct 2010, 1 male, 8 females; B-C, 19 Oct 2010-13 Jan 2011, 4 males, 18 females; B-C, 19 Oct 2010-13 Jan 2011, 2 males, 37 females; B-L, 25 Nov 2010 4 Feb 2011, 14 males, 9 females; K-P, 28 Mar-5 Jul 2012, 2 females; K-P, 5 Jul-13 Nov 2012, 9 females.

Remarks: This is one of the principal species characteristic of caves in Europe (e.g. Franz 1949, Matile 1970, Disney 1994, Weber 1989, Langourov 2002, Prescher \& Zaenker 2005).

\section{Triphleba flexipalpis Schmitz 1927}

Material: V-T, 5 Dec 2009-30 Jan 2010, 2 males, 1 female.

Remarks: This appears to be a new record for Hungary. Schmitz (1949) reported the eggs and larvae on baits of rotting meat. In Germany it has been recorded in deep crevices in limestone in the months of October to December (Prescher \& Sipple 2009).

\section{Triphleba hyalinata (Meigen 1830)}

Material: V-T, 5 Dec 2009-30 Jan 2010, 1female.

Remarks: The larvae are carrion breeders and have featured in forensic cases (e.g. Leclercq $\&$ Watrin 1973, Disney 2006). Adults have been reported from caves in the Balkan Peninsula in winter (Langourov 2002).

\section{SUMMARY}

Four species found in the present study, i.e. Borophaga bennetti, Megaselia tenebricola, $M$ vernalis and Triphleba flexipalpis appear to be new records for Hungary. In the case of $B$. bennetti it is possible that it has been recorded but misidentified as $B$. agilis (Meigen), from which it has only since been distinguished (Disney 2010). Ádam \& Papp (1996, 2001) listed B. agilis as being likely to occur in Hungary.

Of the eleven species recorded, six were only trapped in the basalt cave, three species only in limestone caves and two species (M. rufipes and T. antricola) in both sorts of cave.

Currently, 250 species of Phoridae are noted from Hungary, but the expected number of species likely exceeds 500 (Ádam \& Papp 2001).

\section{ACKNOWLEDGEMENTS}

RHLD's studies of Phoridae are currently supported by a grant from the Balfour-Browne Trust Fund (University of Cambridge).

The authors are grateful to Zsolt Csermák, Attila Piri and Szilárd John for their help in the cave collecting work. Special thanks to the prominently public benefit organization of the Bakonyi Természettudományi Múzeum Baráti Köre and the MTD Hungaria Kft. for supporting the project financially. 


\section{REFERENCES}

ANONYMUS 2012. Országos Barlangnyilvántartás - The Deputy State Secretariat for Nature Conservation and Environment. Available at http://www.termeszetvedelem.hu/index.php?pg=caves].

ÁDÁM L. \& PAPP L. 1996. A check list of the family Phoridae (Diptera) of Hungary. Folia Entomologica Hungarica 57: 65-76.

ÁDÁM L. \& PAPP L. 2001. Phoridae. In: PAPP L. (ed.), Checklist of the Diptera of Hungary, pp. 228-242. Hungarian Natural History Museum, Budapest.

DiSNEY R. H. L. 1994. Scuttle Flies: The Phoridae. London, Chapman \& Hall. XII.+467pp. [Archived by Springer Book Archives - https://www.springer.com].

DISNEY R. H. L. 2001. The preservation of small Diptera. Entomologist's Monthly Magazine 137: 155-159.

DISNEY R. H. L. 2006. Duration of development of some Phoridae (Dipt.) of forensic significance. Entomologist's Monthly Magazine 142: 129-138.

Disney R. H. L. 2009. Scuttle flies (Dipt.,Phoridae) from caves in Spain, including a new species of Megaselia Rondani. Entomologist's Monthly Magazine 145: 153-156.

DISNEY R. H. L. 2010. A new species of Borophaga Enderlein (Dipt.,Phoridae) from the Isle of Man. Entomologist's Monthly Magazine 146: 57-61.

DISNEY R. H. L. 2012a. The females of Megaselia pleuralis (Wood) and two very similar species (Diptera, Phoridae). Entomologist's Monthly Magazine 147: 233-240.

DISNEY R. H. L. 2012b. Scuttle flies (Diptera: Phoridae) caught at dead mice in S. W. Finland. Zootaxa 3298: 30-42.

DISNEY R. H. L. 2012c. Revisionary notes on Palaearetic and Nearetic Phoridae (Diptera). Entomologist's Monthly Magazine 148: 217-226.

DISNEY R. H. L. 2013. An unusually rich scuttle fly fauna (Diptera, Phordae) from north of the Arctic Circle in the Kola Peninsula, N. W. Russia. ZooKeys 342: 45-74.

ESZTERHÁs I. 1986. Az 1986. év szpeleofaunisztikai kutatásai a Bakonyban (Speleofaunistical investigations in Bakony Mountains in 1986). Kézirat (manuscript), pp. 10

EszTerhás I. \& SzENTES G. 2010. Caves Formed in the Volcanic Rocks of Hungary Part II: Caves formed in Basalt, Basalt Tuff and Geyserite. In: MIDDLETON G. J. (ed.), Proceedings 14th International Symposium on Vulcanospeleology, 2010, Undara Volcanic National Park, Queensland, Australia, pp. 189-196.. Organising Group, 14th International Symposium on Vulcanospeleology for the International Union of Speleology Commission on Volcanic Caves, 216 pp.

ESZTERHÁs I. \& SZENTES G. 2013. Geological sketch and the non-karstic caves of the Bakony Mountains in Hungary. Cadernos do Laboratorio Xeolóxico de Laxe, Coruña. 37: 11-36.

FRANZ H. 1949. Erster Nachtrag zur Landtierwelt der mittleren Hohen Tauern. Sitzungsberichte der Osterreichischen Akademie der Wissenschaften 158: 1-77.

HAZSLINSZKY T. 2003. Lóczy-barlang (Lóczy Cave). In: SzÉKELY K.(ed.), Magyarország fokozottan védett barlangjai [Strictly protected caves in Hungary], pp. 365-367. Mezögazda Kiadó, Budapest.

HORUSITZKY H. \& SIEGMETH K. 1914. A magyarországi barlangok és az ezekre vonatkozó adatok irodalmi jegyzéke 1549-1913 [Literature of Hungarian caves and their data 1549-1913], p. 77. A Magyar Királyi Földtani Intézet Kiadványa, Budapest.

KÁRPÁT J. 2003. Csodabogyós-barlang (Csodabogyós Cave). In: SzÉKELY K. (ed.), Magyarország fokozottan védett barlangjai [Strictly protected caves of Hungary], pp. 375-378. Mezőgazda Kiadó, Budapest.

Langourov M. 2002. Scuttle flies (Diptera: Phoridae) from caves in the Balkan Peninsula (Diptera: Phoridae). Acta Zoologica Bulgarica 53: 33-40.

LECLERCQ M. \& WATRN P. 1973. Entomologie et medecinelegale: Acariens et Insectes trouvéssur un cadavrehumain en décembre 1971. Bulletin et Annales de la Société Royale Entomologique de Belgique 109: 195-201.

LERUTH R. 1936. Phorides cavernicoles de Belgique. Bulletin du Musée Royal d'Histoire Naturelle de Belgique12 (36): 1-23.

LERUTH R. 1939. La biologie du domainesouterrainet la faunecavernicole de la Belgique. Mémoires du Musée Royal d'Histoire Naturelle de Belgique 87: 1-506.

LINDBERG K. 1961. Recherches biospéléologiques en Afghanistan. Lunds Universitets Arsskrift N. F. Avd 257 (1): 1-39.

LNDBERG K. 1962. Recherches biospéléologique en Afghanistan II.Lunds Universitets Arsskrift, N. F. Avd 258

(2): $1-15$.

LOKSA I. 1960. Faunistisch-systematische und ökologische Untersuchungen in der Lóczy-Höhle bei Balatonfüred (Biospeologica Hungarica, XI.). Annales Universitas Scientiarum Budapestinensis, Sectio Biologica 3: $253-266$.

MATILE L. 1970. Les Diptères cavernicoles. Annales de Spéléologie 25: 179-222.

PEREZ FERNANDEZ T. 2006. Notasbioespeleológicas. Espeleo (Grupo de Espeleologia de Villacarillo) 18:19-24.

PÉREZ FERNÁNDEZ T. 2007. Alguna notas sobre invertebrados capturados en Cuevas de Jaén, Espeleo (Grupo de Espeleologia de Villacarillo) 19: 27-28.

PRESCHER S. \& SIPPLE R. 2009. Buckelfliegen (Diptera, Phoridae) aus dem Tiefental bei Blaubeuren mit dem Nachweis einer seltengefangen Art. Jahresbericht der Gesellschaft Naturkunde in Württenberg 165: 235-241. 
PRESCHER S. \& ZAENTKER S. 2005.Buckelfliegen (Diptera, Phoridae) aus hessischen Hölen mit einer seltengefangenen Art.Hessische Faunistische Briefe 24: 21-25.

Schmitz H. 1949. Phoridae. In: LINDNER E. (ed.), Die Fliegen derpalaearktischen Region 4 (33) (Lieferung 160): 193240. Stuttgart, E. Schweizerbart'sche Verlagsbuchhandlung.

Weber D. 1989. Die Höhlenfauna und -flora des Höhlenkastergebietes Rheinland-Pfalz/Saarland, $2 . \quad$ Teil. Abhandlungen zur Karst- und Höhlenkunde 23: 1-250.

\section{STRESZCZENIE}

[Nowe dla Węgier gatunki zadrowatych (Diptera: Phoridae) wykazane z jaskiń Gór Bakony]

W trakcie badań prowadzonych nad stawonogami, zasiedlającymi jaskinie górskie (lata 2009-2012, Bakony Mts., Węgry), w materiale zebranym metodą pulapek Barbera, stwierdzono jedenaście gatunków Phoridae. Wśród gatunków zadrowatych, cztery gatunki okazaly się nowymi dla fauny Węgier: Borophaga bennetti Disney, 2010, Megaselia tenebricola Schmitz, 1934, Megaselia vernalis (Wood, 1909) i Triphleba flexipalpis Schmitz, 1927. 